Research Paper

\title{
The Role of IPR in Plant Genetic Engineering
}

\author{
Abhishek Rajesh Bhattacharjee ${ }^{1}$, Shreya Das ${ }^{1}$, Stuti Aastha ${ }^{1}$ \\ ${ }^{1}$ Amity Law School, Amity University, Newtown, Kolkata, India.
}

Article History

Received:

05.08.2020

Revised:

11.09.2020

Accepted:

19.09.2020

*Corresponding Author:

Abhishek Rajesh Bhattacharjee

Email:

abhishek.bhattacharjee314@gmail.com

This is an open access article, licensed under: $C C-B Y-S A$

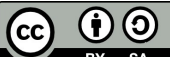

Abstract: This research develops an interactive module system that can be used to explore and build a self-assessment checklist on significant learning content in the daily life and work of students in the future. The role and status of Patent laws in the protection of plant species which have been genetically modified is currently uncertain in India. Discussions and debates regarding the same are rife and experts have different views regarding the whole aspect concerning economical and ethical considerations. Genetically engineered plants and modified crop plants are of significant economic value. In India, they face critical challenges, for instance, the requirement of dependable public policies and vigorous frameworks for regulatory control. This becomes much more vital since India desires to be an economic superpower primarily based on innovation. It is very important for a person from the legal field, especially those interested in the field of IPR, to have clarity regarding the protection of genetically modified plants. This humble attempt at a research paper seeks to clarify the same and discusses the various aspects on which one should think while concluding their views on the topic.

Keyword: Ethical Considerations, Intellectual Property Rights, Patent Laws, Plant Species, Regulatory Control. 


\section{Introduction}

Although there are shreds of evidence of displacement of varieties of plants and biodiversity with the help of natural routes since ancient times, it was during the middle of the 1960s that Dr Norman Borlaug of Mexico created the foremost high-yielding variety of wheat seeds. Subsequently, the technology was followed all over the world. In 1966, the development of the high-yielding variations of wheat under the "High-Yielding Varieties Program (HYVP)", was introduced and further facilitated in India [1]. India has always been a country where the majority of people earn their livelihood through agriculture. Post the British era, $80 \%$ of the population were dependent upon agriculture for their daily bread and butter. Even today, about $55 \%$ of the population earn their livelihood, either directly or indirectly, through farming. Implementation of the HYVP helped in overcoming the food catastrophe faced by Indians in the 1960s which was life-threatening. Due to the HYVP, there was a rise in agricultural productivity which in turn led to the Green Revolution picking up momentum in the country. This factor played a very major role in ensuring self-sustainability in the Indian economy.

As the country entered the new epoch, an increased cost of living along with an expanded population accompanied by a lack of access to resources, there arose a necessity and call to restructure the agriculture of the country by adopting the "Gene Revolution". Two technologies evolved for shaping up the subsequent insurgency in plant-related and agricultural technologies in India. The first innovation is related to the "recombinant DNA technology (rDNA) that was established by Herbert Boyer and Stanley Cohen, eminent personalities in the field of biotechnology who started by developing the fundamental phenomenon of transporting genetic substance from one organism and artificially inducing it into the genome of another organism, where the genetic material so transported gets stimulated and expressed by the other organism [2].

The "Genetically Modified Species" based on this technology, vary from old-style approaches in nature and previous traditional programs on plant breeding as they do not include general mingling of the genes between various plant types. Rather, these genetically modified organisms comprise of a very choosy and accurate transport of DNA from one creature carrying anticipated stretches of genetic matter that can transfer chosen behaviours to the recipient organism by engaging tissue culture methods. The above-mentioned technology has been familiar in the domain of agriculture and plantrelated biotechnology, as providing valuable tools. Products utilizing identical apparatuses have been expansively used to produce "Genetically Modified Organisms" and "Genetically Modified Plants". The second technique, which has also been path-breaking, is the "Clustered Regularly Interspaced Short Palindromic Repeats (CRISPR) technology, which is a feature of the bacterial defence system that has been adapted and modified to make them the foundation for CRISPR-Cas9 genome expurgation technology accompanied with other alternate systems [3]. It can alter the agricultural and biotechnological fields, both economically as well as technologically. Utilizing such practises has the potential to change the technological and economical division of the country's agriculture.

Similar to the "Green Revolution", which was a revolutionary acceptance of ground-breaking technical know-how that facilitated India to produce more than enough food for its population, the implementation of various technologies as mentioned above and "Genetically Modified Plants" had a big influence on the agricultural sector of the country. The necessity of dependable laws, policies, and healthy frameworks for supervising control pose noteworthy tests for genetically manufactured crops in India. The IP framework is strict in its ambit, and the existing judgments prevent fortification of the technical methods for the growth of "Genetically Modified Plants" under the prevailing provisions of Patents law in the country. This would possibly aid in disincentivizing players who have advanced proprietary methods by conveying their modern creations for utilization by farmers in India.

There has been an attempt to study the integration of biotechnology and IPR, assuming that the legal background of the same is enveloped by several complications, hence a straight-jacket formula cannot be put into place to study it. Through intensive study of various sources, the researchers have tried to bring forth the science and technicality behind the genetic modification of plants and various aspects of international law that govern the arena, since the genetic modification of plants is a global phenomenon. Also, through a case study, the very modern and possibly appropriate approach of the Indian courts towards the same has been studied. Conclusively, the researchers want to emphasize the importance of IP laws - both national (India) and international - in plant genetic engineering and provide one of many possible perspectives to study the same.

The purpose of this research paper is to analyse the current scenario concerning safeguards granted 
to genetically engineered plants in India under the domain of IP Laws. The momentous amount of economic value attached to the genetically modified plant species cannot be denied. It is for this reason that the study carried out through this paper becomes very much important. The paper also includes within its ambit, the distinction between different procedures dealing with plant genetic engineering, whether the processes qualify as 'essential biological processes,' and what is their status under the Patents Act, 1970.

\section{Methodology}

Researchers have selected the topic to address the significant and impelling need of clarifying the subject matter in question. The method opted for this research paper is a doctrinal one which includes analysing the IP protection available to genetically modified plants in India through the relevant provisions of law and a very important case study. The questions or doubts have been clarified using a qualitative approach. Both legal as well as non-legal authorities such as International legal instruments, appropriate provisions of law, case analysis, books of both national as well as international repute, international law journals, trusted online sources, international journals on plant genetic engineering, reports and opinions of experts \& research scholars have been dealt with in its entirety to collect the material information required for this research paper.

\section{Result and Discussion}

\subsection{Plant Genetic Engineering and The Trips Agreement}

The World Trade Organisation is under an obligation under "TRIPS" to give protection under patent law to its members [4]. The protection provided shall be for two things i.e. the product as well as the process. All fields of technology shall be included under it, provided that the inventions are new, capable of having an industrial application, and involve innovation. The protection shall only be provided to microorganisms and plants \& animals shall be omitted from it. Biological procedures for the creation of plants \& animals shall not qualify to get any protection under patents but protection shall be extended to non-biological or microbiological processes. However, plant varieties are to be given mandatory protection. The "TRIPS Agreement, under Article 27(3) (b) deals with protection to plant varieties [4]. This particular provision states the items which are to be excluded from being protected under the patent law. However, the exception laid down under this provision states that adherents of the WTO shall only shield the plant varieties either under patents or under a "sui generis" scheme or a blend of both of them. Protection shall not be extended to plants, animals \& other micro-organisms and also the biological procedures for preparing such plants, animals, and micro-organisms.

Therefore, on reading the above provision, it can be concluded that though no protection has been provided to plants, a guard has been extended to plant variations. Followers of the WTO are also under an obligation to protect plant varieties under their municipal laws either under patents or under a "sui generis" scheme or a mixture thereof. The requirements for patent protection have been provided under the TRIPS agreement which includes newness, non-obviousness, and its applicability in the industry/usefulness. However, neither a detailed explanation to it has been provided under the agreement nor does it describe in detail the room of protection of patents on genetic matters and biotechnological procedures. Only minimum standards have been set out under. Therefore, the members shall not be obligated to grant protection which is more extensive in nature than provided under the TRIPS agreement. The protection provided by certain member states does not stand as an obligatory factor for other member states to provide that same amount of protection if the TRIPS agreement does not provide a mandate for doing so. It is also not required for a member state to provide identical safety to the nationals of all other member states as provided to its nationals.

As stated above, in a case where the member states do not provide any guard to plant varieties under patents, protection is to be provided under the "sui generis" scheme or through a blend of both. Though the term "sui generis" has not been defined under the agreement, it means "setting up a system of its kind, i.e. creating a separate national law or establishment of international norms that would afford protection to IP which would be dealing with genetic resources or biodiversity [5]

\subsection{Patent Protection In India For Genetically Modified Plants}

On studying the technology involved, it may quite firmly be established that a transgenic plant is a GMO since there is a case of artificial transfer. India ratified TRIPS, following which the Ayyangar 
Committee's recommendations in its report were enacted in India in the form of the Patents Act. This report had also unambiguously elucidated on the issue of certain prohibitions under "Section 3(h) of the Patents Act. These prohibitions excluded methods of agriculture or horticulture from patentability [6]. The intent for it was to apply to creations in the arena of plant proliferation by nonsexual means. The current stance of the Indian Patent Office has been seen as to acknowledge and account every usual practice done in an open field as a system of agriculture. As a consequence, any claim in a patent application that is marked as containing terms such as 'germinate,' 'seeds,' 'hybrid,' 'variety,' etc. is deemed to be excluded from patentability.

In 2002, Section 3(i) of the Patents Act was amended. Before the amendment the Section read as follows:

"any process for the medicinal, surgical, curative, prophylactic or other treatment of human beings or any process for similar treatment of animals or plants to render them free of disease or to increase their economic value or that of their products [6].

Post amendment, the phrase "or plants" was struck out. Thus, the handling of plants to purify it or to grow its monetary value does not come under any of the segregations as under Section 3. Further, "Section 3(c) of the Act excludes the discovery of 'naturally occurring living things' or 'non-living substances' from patentable subject matters [6]. 'Discovery' does not, however, include DNA that has been modified, a recombinant DNA construct, or any modified protein molecule as they require substantial human intervention and lab work. These aren't thus patentable for the stated reason. Furthermore, "Section 3(j) of the Act excludes parts or whole of plants and animals, seeds, varieties and species and essentially biological processes for creation or dissemination of plants and animals, from the patentable subject matter [6]. Microorganisms are not excluded.

The conventional methods utilised by India as it positions itself to produce or propagate a plant or an animal variety is that they aren't patentable matter. Opposing explanations of what is enclosed under "... any part of a plant" as under Section 3(j) of the act and the clash between the said Act and the Protection of Plant Varieties and Farmers' Rights Act, 2001 is best exhibited through case laws. The researchers have studied the following case and attempted to analyse the practical aspect of the research topic.

\subsection{The Monsanto Technology Case}

\subsubsection{Facts of the Case}

Monsanto Technology LLC is an agrochemical and agricultural biotechnology corporation and was one of the first companies to successfully modify the genes of seeds and plants as a branch of agrobiotech activities. Biotechnology has developed in recent years, and Monsanto puts those discoveries to use concerning advancing essential such as wheat, corn, cotton, soybeans, etc. Patents regarding genetically modified food (GMO) and biotechnology-associated plants are largely in the name of Monsanto. In India, Monsanto operates as a joint venture - Mahyco Monsanto Biotech Pvt. Ltd. (India).

Nuziveedu Seeds is an established seed company in India, with a couple of subsidiaries. Mahyco Monsanto Biotech Pvt. Ltd. (India) is known to license its biotechnologically modified products to various seed companies in the domestic arena. In furtherance of this activity, Monsanto entered into a licensing agreement with Nuziveedu Seeds on $21^{\text {st }}$ February 2004, the initial period of which was 10 years, which was further prolonged by an additional year in 2014. This licensing agreement was related to entitling the defendants to advance and commercialise "Genetically Modified Hybrid Cotton Planting Seeds, granted to Monsanto India, with the help of Monsanto's technology [7]. These patented seeds provided higher yield because they were resistant to boll-worm attacks. For granting this license, Monsanto India charged not only a lifetime fee of Rs. 50 lacs, but also periodic trait-value compensation. Various state governments of India, at that time, started formulating and passing novel guidelines for price regulation, thus the Indian companies who were given licenses by Monsanto requested the latter to lessen the trait-value fee. However, Monsanto rejected to do it.

The Indian companies in question then stopped disbursing the royalties, accruing to which Monsanto took action on $14^{\text {th }}$ November 2015. An application for the granting of an injunction was filed by Monsanto, claiming trademark infringement and violation of registered patent, owing to the 
sudden and before-time termination of the licensing agreement. As a means of recovering compensation, Monsanto initiated arbitration proceedings. The amount they quoted from the Indian companies was Rs. 400 crores.

Nuziveedu filed a counter-claim under Section 64 of the Patents Act, 1970, relying on the following grounds under the provision [6]:

1. Absence of novelty

2. Absence of obviousness

3. Complete specification not revealing any "invention"

4. Deficiency in complete specifications

5. Deficiency in claim

6. False suggestions or representations

7. Non-compliance of the requirements of Section

8. Non-disclosure of source or geographical origin

9. Invention claimed in the complete specification being not useful

Nuziveedu also brought forth Section 3(j) of the Act, which was serving as the imminent cause for withdrawal of the said patent and argued further focused on the same. The Protection of Plant Varieties and Farmers' Rights Act, 2001 acted as their main defence towards the protection of rights.

\subsubsection{Court Arguments}

\subsubsection{Patent No. 214436 vis-a-vis Understanding of Section 3(j) of the Focus Statute}

Nuziveedu's primary contention was that "Section 3(j) excludes certain things from the ambit of 'inventions' [6]. Since seeds \& varied species of plants and any biological method for creation or proliferation of plants \& animals is such an exception, Nuziveedu emphasised that claim 25 of the Patent relates to "nucleic acid sequence [6]. The sole terms in which the sequence can be applied is "a plant cell, a seed, a transgenic plant or a plant variety [7]. In this case, the plant and seed having a nucleic acid arrangement comprising of the Cry2Ab gene could not be approved a patent in India as these specifications the condition of 'industrial application' was missing. Failing this, they fell under the aforesaid exclusions. Nuziveedu further said that the "BT Trait in any cotton hybrid-variety plants was a biological process; hence they are to be regarded as 'natural discoveries' made in a laboratory through cross-breeding [7].

Monsanto India rebutted with two broad contentions - one, that the term 'plant' would be subject to interpretation as a 'living organism' with regards to Section 3(j) and two, that the exclusions mentioned in "Section 3(j) would apply only to biological beings and not creations as in this case, the mischief of the provision was escaped by the product in question fitting into the mould of 'microorganisms' which have been specifically mentioned as to not fall within the exceptions [6]. Monsanto went further to explain that it was the DNA that was responsible for any and every process in a living creature and a DNA segment is a code that assists in producing protein, thus not making either of these individually a living thing in any case. The Claim Numbers 25 to 27, which were the subject matter of the patent were artificial, manufactured DNA orders. These sequences possessed the CryAB gene, which on being incorporated into a plant's genome, conferred plants with insect resistance. They stressed that no fragment of the DNA order - as is in this case, a gene - is a living creature and thus DNA cannot be termed as a "part" of a plant. No physical attribute of a plant and any of its parts or an organ of an animal is the matter of dispute herein and it is only a method of creating new and inventive transgenic varieties that would bring it well within the ambit of The Patents Act, 1970.

\subsubsection{Applicability of the PPV\&FR Act, 2001}

The term 'micro-organisms' has not been defined in the "PPV\&FR Act, 2001 [8]. The defendants, therefore, referred to the acclaimed Cambridge Dictionary and stated that a micro-organism is "A living thing that on its own is too small to be seen without a microscope, such as bacteria, germs, viruses [9]. Nuziveedu effectively negated Monsanto India's argument regarding their patent claim. The TRIPS agreement which India has ratified was brought into the light, and Nuziveedu reiterated that it was through the push provided by TRIPS Agreement that the Plant Variety Act was enacted as distinct legislation from The Patents Act, 1970. The main purpose of the Act was to encourage the development and fortification of plant variations and safeguarding the rights of breeders. The 
conclusion to their argument was that in the given case, seeking patent protection was an invalid action as the product ought to be protected by and under the provisions of the PPV\&FR Act, 2001.

In their contentions, Monsanto India re-emphasized that the patented DNA is outside the scope of the term 'plant variety'. A plant or portion/portions of the plant which could be utilised to proliferate the variety, a trait of a plant, chemical, or other constituents (oil, DNA, etc.), and a plant breeding technology are all excluded from the definition [10] A DNA segment cannot come under the term 'plant variety' and it would be deprived of such registration on the justification that it does not fulfil the circumstances precedent in "Section 2(za) read with Sections 14 and 15 of PPV\&FR Act [11].

Further, Monsanto elaborated on the modifications made to The Patent Act, 1970 in 2002 and 2005. They said that when Sections 2(1) (j) and 3(j) would be read with the objects and reasons of these modifications, certain salient features of the Bill would be brought to light. Firstly, it would be the one related to modifying Section 3 of the Act and broadening its interpretation to include those exclusions that have been laid down by the TRIPS Agreement. To add materials like detection of any living or non-living things which occur in nature to the list of exceptions which in general circumstances do not comprise patentable invention would be the second aspect.

They concluded by submitting that their work was a result of innovation and skill, as they were inventions and products of the processes of biotechnology. Thus, the patented invention would be guarded under the PPV\&FR Act, 2001, leaving the process to be validly patented.

\subsubsection{TM Abuse and Sub-Licensing issue}

The appellant argued that according to the facts, Nuziveedu had stopped paying trait value to Monsanto India even though the former was utilising the latter's technology. The termination of the sub-licensing was thus perfectly legal. Monsanto were the holders of the trademarks BG I and BG II and had applied for an injunction to bar Nuziveedu from using the same. Finally, since the license agreement stood terminated and not restorable, the obligations contained therein also ceased to be binding upon the parties. Hence, the duty to perform the obligations under Section 14(1) of the Specific Relief Act, 1963 also stood negated.

The first claim of Nuziveedu was that seeds fall under the scope of "essential commodity" [11]. Hence, it is only the Central Government, which is empowered to decide upon and declare the trait value of seeds. If such value is surpassed by a company, any licensing agreement would not be liable to be terminated on grounds of non-payment of the fees by the licensee to the licensor. There was also a rebuttal to Monsanto relying on Section 42 of the Specific Relief Act; it was asserted once again by Nuziveedu that it was not bound to oblige Monsanto in any way by paying the trait fees fixed by the latter since it was only the Central Government, which was entitled to fixate upon the same. It is thus conclusive that the relief under the said provision effectively negates the present case. The validity of terminating the licensing agreement was thus questioned, as it seemed to be an arbitrary decision taken by Monsanto India to harass the licensee. Nuziveedu's penultimate submission was that since Monsanto India was responsible for neglecting the fact that protection for the product in question could only be sought under the PPV\&FR Act, 2001, there was an avoidance of the provision of benefit sharing with the companies in the seed business who produced and marketed new BT Cotton plant variations expressing BT trait [12].

As far as the Trademark violation allegedly done by Nuziveedu was concerned, the defendants claimed to have made use of the abbreviations of Monsanto's trademark. The intention was to indicate the source which had been used for product manufacturing. Thus, the use would be classified as a legitimate "descriptive mark" [9]. "Moreover, infringement of a trademark can only be said to have occurred if a registered mark is used as 'trademark' and not in any other case [13]

Monsanto India further rebutted these arguments. Reference was made by them to the Percy Schmeiser case [14]. Herein, the Court had applied the Doctrine of Purposive Construction to similar facts, and ultimately held that there had been "use" of the patent granted to Monsanto when an unauthorised person utilised the patented gene to develop and further commercialize a seed variety; hence there was an infringement of the aforesaid patent. Since the DNA segment was existent all over the seed and it gave it an advantageous trait, there was said to be a significant and noteworthy contribution of the patentee. A similarity was drawn to Nuziveedu's actions in the present case, where the hybrid seed which had immense tolerance towards the harm generally caused by insects as a result of the DNA sequences which were infused in them; the sequence patented to Monsanto. Hence, there was a violation of patent rights when the final product was brought to the front. 


\subsubsection{Judgement and Analysis}

March 2017 saw the Hon'ble High Court at Delhi necessitating the requirement of formal proof, in the form of expert opinion being the top priority. The extent of domination approved by the patent claims could only be appropriately adjudged in these kinds of complicated matters involving patents based on such expert opinion. The sub-license agreement entailed certain obligations which both parties were instructed to remain bound by, throughout the pendency of the case proceedings. In that course, the laws in force at that point would have governed the license fee/trait value which was payable by the defendant.

Distressed, both the parties favoured appeals. The two-judge appellate bench of the DHC upheld that the protection under the PPV\&FR Act, 2001, and the Patent Act are mutually exclusive from each other and not complementary measures. It was opined by the Court that therefore, protection had to be sought by Monsanto India under the PPV\&FR Act, 2001, according to the realities and situations of the case. Further, the court observed that Section 10(4) of the Patents Act had not been complied with by the respondents as they had not disclosed the required details regarding the source of the said 'invention.'

The Court ultimately held that the subject matter falls inside the exclusions stated in Section 3(j) of the Patents Act, which essentially makes the product non-patentable. The Court declared that the respondents ought to claim restoration of their right in the disputed patent and the patented invention, given they applied and obtained registration over the subject matter under the proper and appropriate law within a time-limit of three months from the date of order i.e. $11^{\text {th }}$ July 2018 . Insofar as the infringement of a trademark by appellants was concerned, the same was excused as covered within the ambit of Section 2(o) of The Trademarks Act. The respondent, as mentioned earlier, had claimed damages worth Rs. 400 crores from the licensees, which was held to be wrong, by the court.

The facts and technical methods involved in the patent were immense and intense and were heard by the Hon'ble Supreme Court of India in as much detail, with as much attention as was deemed appropriate. However, it desisted voicing any opinion on any of those issues when it gave a judgement on January 8, 2019, in the present case. It noted that very elaborate submissions had been made in front of it, given that the facts were exceedingly technical and so were the processes involved throughout, which gave rise to the dispute. However, on this front, the Court concluded that because of the nature of the order that is sought to be passed, all the above information stood irrelevant at that stage. All questions of law and fact, the Court said, ought to be considered in suitable proceedings.

An important point to be noticed was that the defendants had made a counter-claim at the early stage which was not considered by the Delhi High Court. The plaintiffs had favoured an appeal against the injunction order against them regarding the issuing of license fees. The Division Bench to which the appeal had been preferred ought to have restricted itself to adjudge only if the grant of the injunction by the single judge bench was correct or incorrect, given the actualities and conditions of the case. It was an error on the part of the Division Bench to have scrutinized the counter-claim itself, which was a borderline infringement of the dominion of the single-Judge Bench to decide nonpatentability of the process claim 124, that too in the summary manner it was done. This was not a permissible move in the eyes of law, let alone being desirable. Evidence was required to be examined to answer the exceedingly complicated questions of fact and law involved in the case, mainly associated with the patentability of things and exclusion of such rights in certain cases.

The Court took into account the provisions of "Section 64 of The Patents Act, 1970" and Section 9, Order 12 Rule 6 and Order 16 of "Rule 1 of the Civil Procedure Code, 1908" and was satisfied that the Division Bench made a grave error in disposing of the suit. The Court pointed out that only documents extracted from the public domain which had not even been filed as exhibits in the suit had been relied upon by the Division Bench to make the decision. The observation in the case of Alka Gupta vs. Narender Kumar Gupta was taken into account wherein it was noted that "a civil proceeding governed by the Code will have to be proceeded with and decided according to the law" [15]. That, alongside the provisions of the Code, would be the deciding factor as opposed to the whims of any court. Unless given under the law, there should be no short-cuts in the trail of litigations. A step-by-step process in a case cannot be cut down upon by determining issues of fact simply on pleadings and documents produced without a trial. In light of all the notations so made, the order of the Division Bench was set aside. The Supreme Court upheld the initial order of the Delhi High Court and redirected the case to the same for disposal in accordance with appropriate laws. The appeals and the intervention applications were disposed of. 
It is quite clear that the Supreme Court of India is intent upon having a case-to-case approach as far as issues related to patenting GM plants is concerned since there are a lot of technicalities and special knowledge involved. The position of patent fortification for "Genetically Modified Plants" is currently ambiguous in India and is a flaming dispute, the arguments for and against which have to be framed with monetary and moral considerations. The requirement for reliable public policy and vigorous frameworks for supervisory control is especially important considering India's desire to adopt and step towards an innovation-based economy. That also gives birth to vital challenges to the whole idea of introducing India to genetically engineered or modified crop plants.

\subsection{Farmer's Rights Act, 2001 and Plant Varieties}

The Government of India formulated the abovementioned act according to the standards laid down by TRIPS, regarding setting up a "sui generis" system. The Act has also been made in consonance with the International Union for the Protection of New Varieties of Plants (UPOV), 1978, and the standards laid down therein. The main objective behind the formulation of the legislation was to guard the rights of the breeders and also to provide an incentive for the invention of novel plant variations.

To implement this legislation, the Protection of Plant Varieties and Farmers' Rights Authority was established on $11^{\text {th }}$ November 2005. There are a total of 15 members appointed by the Government of India and apart from that; the Chairperson is the Chief Executive Authority. "A variety is eligible for registration under the Act if it essentially fulfils the criteria of Distinctiveness, Uniformity, and Stability (DUS) [16].After the registration is completed, a certificate of registration shall be provided which shall be valid for a period of nine years in case of trees \& vines and a period of six years in case of crops. The registration can also be renewed on the payment of the requisite fees but in no circumstance shall it go beyond a period of eighteen years in case of trees \& vines and fifteen years in case of crops. The issues arising out of this particular statute shall be looked into by the "PVPAT" [17]. An appeal can be filed against the decision given by the PVPAT to the High Court.

\section{Conclusion}

To build-up an innovation-based economy, it is very much necessary to clarify the scope of protection of the technological processes required for developing the genetically modified crops and trees. However, in the case analysis, we saw that the Apex Court has not yet given any interpretation of section 3(j) of the Patent's Act, 1970. It has dismissed the case on the ground that it did not follow the proper procedures of law i.e. expert evidence was not taken, which was an essential part of this proceeding as the matter involved chemical and biotechnological issues. The matter has been returned to the Delhi High Court. Therefore, a clarification of the judiciary on the required provisions of the Act is the need of the hour to understand the scope and extent to which the Act can be applied and move ahead with the inventions accordingly.

Though an interpretation of the above section is yet to be provided by the Apex Court, referring back to the TRIPS agreement and the submissions made by the Legislature afore the 2002 modifications of the Patent law, it seems to be quite evident that patentability of plants, plant varieties, and even seeds was kept excluded from the jurisdiction of the Patent Act and they were left to be governed by the Farmer's Rights Act [9]. TRIPS had provided an open option to the countries to give protection to plant varieties either under patents or a sui generis system or a combination of both. A statutory review was scheduled by the signatory states whereby each of them represented their views on the given article. India had also provided its views against the same. After going through the submissions made by the various ministries, it was prominent that only "Genetically Modified Organisms" can be protected under the existing domestic law. However, plant varieties were seen to be excluded from the purview of patentability. The same was prescribed to be governed by the Plant Varieties and Farmers Rights Legislation. These submissions and reports were the foundation on which the modification was based on, excluding plant varieties. Therefore, from the entire study made above, it can be concluded by stating that the legal framework on the rights of the breeders, biotech companies and farmers have been made in a balanced way so that none of their rights gets violated. India has protected the rights in such a manner that any of them doesn't get violated. Among the options provided under the TRIPS agreement, India has chosen to provide a combination of patents and sui generis system to protect genetically modified organism and only sui generis system has been used to provide protection to plant varieties. 


\section{References}

[1] K. Yadav, The High-Yielding Varieties Program. Agropedia. [Online]. Available: http://agropedia.iitk.ac.in/content/high-yielding-variety-programme. [Accessed: June. 26, 2010].

[2] C. Webb, Introduction to Engineering Fundamentals of Biotechnology. Manchester: The University of Manchester, 2011.

[3] K. C. Liu and U. Racherla, Innovation, Economic Development, and Intellectual Property in India and China. Singapore: Springer Singapore, 2019.

[4] UPSTO, "Agreement on Trade- Related Aspects of Intellectual Property Rights," United States Patent and Trademark Office. 2017. [Online]. Available: https://www.uspto.gov/ippolicy/patent-policy/trade-related-aspects-ip-rights. [Accessed: November. 6, 2019].

[5] IPTF Luncheon, Is a Sui Generis System Necessary?. New York City: IIPI, 2004.

[6] B. P. S. Singh, The Patents Act, 1970. India: Intelectual Property India, 2015.

[7] P. Sinha, Monsanto Technology LLC And Ors Vs. Nuziveedu Seeds Ltd. And Ors. Mondaq. 2018. [Online]. Available: https://www.mondaq.com/india/trademark/701912/monsantotechnology-llc-and-ors-vs-nuziveedu-seeds-ltd-and-ors. [Accessed: November. 6, 2019].

[8] C. J. McLachlin, G. L’Heureux-Dubé, M. Iacobucci, B. A. Bastarache, and J. LeBel, Harvard College v. Canada (Commissioner of Patents), (2002) 4 SCR 45. Canada: Supreme Court of Canada, 2002.

[9] Indiacode, The Protection of Plant Varieties and Farmers' Rights Act, 2001. India: Acts of Parliament, 2001.

[10] Cambridge. (n.d), Meaning of microorganism in English. Cambridge Dictionary, 2020. [Online]. Available: https://dictionary.cambridge.org/dictionary/english/microorganism. [Accessed: May. 28, 2020].

[11] UPOV, International Convention for the Protection of New Varieties of Plants. Geneva: UPOV Publication, 1991.

[12] Legislative, The Essential Commodities Act. 1955. India: http://legislative.gov.in/sites/default/ files/A1955-10.pdf. [Accessed: November. 6, 2019].

[13] Ministry of Law, Justice, and Company Affairs, The Trademarks Act, 1999. India: Acts of Parliament, 1999. [Accessed: November. 6, 2019].

[14] C. J. McLachlin, M. Iacobucci, B. A. Bastarache, D. LeBel, and J. Fish, Percy Schmeiser v. Monsanto, 20041 SCR 902. Canada: Supreme Court of Canada, 2004.

[15] R. V. Raveendran and H. L. Gokhale. Alka Gupta vs. Narender Kumar Gupta (2010) 10 SCC 141. India: Supreme Court of India, 2010.

[16] Vikaspedia, Protection of Plant Varieties and Farmer's Act. India, Vikaspedia, 2001. [Online]. Available: https://vikaspedia.in/agriculture/policies-and-schemes/crops-related/protection-ofplant-varieties-and-rights-of-farmers/protection-of-plant-varieties-and-farmers-rights-act-2001. [Accessed: March. 14, 2020].

[17] Department of Agriculture and Co-operation., The Plant Varieties Protection Appellate Tribunal (Applications and Appeals) Rules. New Delhi: Ministry of Agriculture, 2010. 